\title{
A Comprehensive Customer Brand Engagement Model Including Purchase History Data:
}

Empirical Research Using Customer Data for a Fashion Accessories SPA Brand

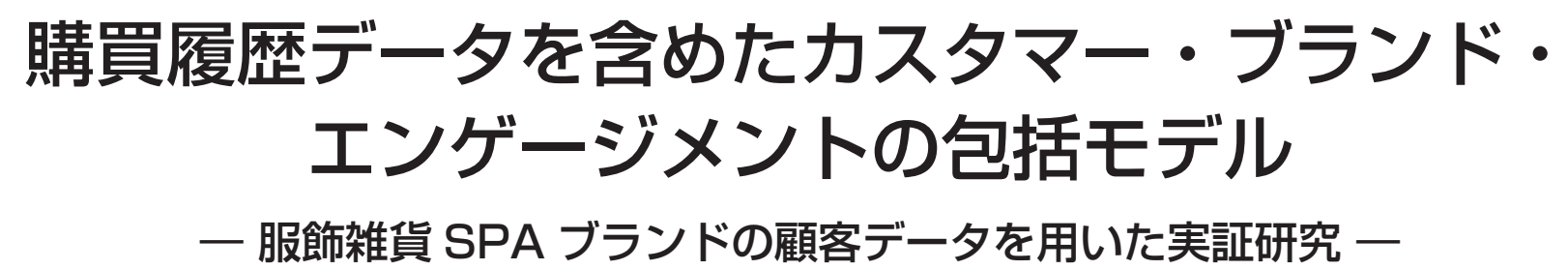

\author{
Hiroyuki Takahashi ${ }^{* 1}$ \\ 同志社大学 商学部 教授 \\ 高橋広行
}

${ }^{* 1}$ Professor, Doshisha University Faculty of Commerce, Japan, h_takahashi@mbf.nifty.com

\begin{abstract}
In recent years, customer brand engagement has received increasing attention in both practice and academic research. The purpose of this study is to measure customer brand engagement as a subset of cognitive, affective, and behavioral factors, and to clarify the position of engagement and its relationship with purchase behavior using a comprehensive model that analyzes purchase data and brand evaluation, satisfaction, and loyalty simultaneously. Using this model, we identified the relationship between engagement and purchase behavior. We integrated a questionnaire survey and purchase data of customers for a fashion accessories SPA brand, and analyzed these data with a structural equation model. The results showed that engagement is positively related to the length of customer period, total purchase amount, and number of purchases via satisfaction and loyalty. On the other hand, the direct path from engagement to purchase behavior was negatively related, indicating that engagement does not lead to purchase behavior unless it goes through satisfaction and loyalty.
\end{abstract}

Keyword : Brand loyalty, Customer brand engagement (CBE), Satisfaction, Purchasing behavior, Purchase data

要約 : 近年, 実務でも研究面でも, カスタマー・ブランド・エンゲージメントの注目が高まりつつある。そこで, 本研究の目的 は, カスタマー・ブランド・エンゲージメントを認知的·感情的·行動的な 3 要素のサブセットで測定し，ブランド評価や満足 度, ロイヤルティとともに, 購買履歴データを同時に分析する包括モデルを通じて, エンゲージメントの位置付けとともに, 購 買行動との関係を明らかにすることである。服飾雑貨 SPA ブランドの顧客に対して行なった質問票調査と顧客の購買履歴デー 夕を統合し, 構造方程式モデルで分析を行った。その結果, エンゲージメントは, 満足度とロイヤルティを経由し, 購買行動の 「顧客期間」、「購買金額」「購買回数」と正の関係にあることがわかった。一方, エンゲージメントから購買行動への直接のパ スは負の関係であったことから, エンゲージメントは満足度とロイヤルティを経由しなければ, 購買行動には至らないことも同 時に明らかにした。

キーワード : ロイヤルティ, カスタマー・ブランド・エンゲージメント (CBE), 満足度, 購買行動, 購買履歴データ

Information : Received 16 August 2021; Accepted 16 November 2021; J-STAGE Advance published 11 February 2022

\section{I. 問題意識}

ブランド・ロイヤルティは, ブランド・エクイティに
おける最も重要な要素であり, 顧客が継続的に購買し続 けてもらうための重要な指標の一つである（Keller, 2008)。このブランドと顧客との関係を構築する研究と

して, ブランド・リレーションシップの研究がこの 30 
年の間に進んできた。特に近年においては，購買のシー ンにとどまらない顧客とブランドとの「経験的な関わり あい」としてのエンゲージメントに関する研究が，実務 と研究領域の両方に扔いて, 非常に重要なトピックになっ てきている（cf. Hollebeek, Glynn, \& Brodie, 2014; Leckie, Nyadzayo, \& Johnson, 2016; Vivek, Beatty, \& Morgan, 2012)。

この顧客とブランドとのエンゲージメントが重視され てきた背景には，インターネットとともにデジタルッー ルやSNS の発展によって, (購買を通じた接点以外にも) 顧客とのタッチ・ポイントが増加したことが影響する (Rosado-Pinto \& Loureiro, 2020)。ブログや SNS への 「いいね!」やシェア，コメントに加え，行動履歴（口 グ）も取れるようになり，ブランドと顧客との関係が可 視化できるようになってきたため, マーケターは, 満足 度とロイヤルティだけを見ているだけでは不十分な状況 になってきている（Pansari \& Kumar, 2017; Rosado-Pinto \& Loureiro, 2020)。

そこで, 本研究の目的は, ブランド評価やアプリ活用 度といったカスタマー・ブランド・エンゲージメントに 影響する要因と, 満足度・ロイヤルティに加え, 購買行 動を含めた包括モデルで分析することで，エンゲージメ ントの位置づけとともに, 購買行動との関連を明らかに する。

\section{II. 先行研究レビューと仮説モデル}

\section{1. エンゲージメントの先行研究レビュー}

マーケティング分野におけるエンゲージメント研究の 概念は, 1980 年ごろから発展してきたリレーションシッ プ・マーケティングと, サービス・マーケティングを基 にした，ブランドと消費者との相互作用に関する研究の 流れに沿いながら発展してきた（Adhikari \& Panda, 2019; Rosado-Pinto \& Loureiro, 2020)。エンゲージメント研究 がスタートした当初は，コンセプチュアルな研究や質的 研究が主であり，その対象も，顧客とブランドの関係だ けでなく, 広告やオンライン・コミュニティ, SNSに対 するエンゲージメントなど，幅広い分野が対象になって きた（Hollebeek et al., 2014）。近年は主に顧客とブラン
ドとのエンゲージメントを測定する研究が進みつつあり， 認知・感情・行動の 3 つの側面を含んだカスタマー・ブ ランド・エンゲージメントの尺度開発が徐々に増えつ つある (e.g. Eigenraam, Eelen, Lin, \& Verlegh, 2018; Fernandes \& Moreira, 2019; Hollebeek et al., 2014)。これ らの先行研究に従い，本稿に打けるカスタマー・ブラン ド・エンゲージメントの定義を「消費者がブランドと積 極的に関わり，相互作用の中で形成される（購買にとど まらない) 認知的・感情的・行動的な関倸」（以下，エン ゲージメント）として進める。これまでのエンゲージメ ント研究に扔ける課題は, ロイヤルテイとの関係を量的 に検証した研究はまだ少なく（Fernandes＆ Moreira, 2019), 購買行動との関連性を確認した研究は見られな いため, 本研究では上記を含めた包括的なモデルを通じ て，この点を明らかにすることを目的とする。

\section{2. 仮説モデル}

エンゲージメントの位置づけをふまえ，仮説モデルを 設計する。顧客とブランドとのエンゲージメントは, 購 買前の接点や購買後のブランドの使用や経験といった多 様な状況の中での関わりを通じて形成され，このような ブランドと消費者との相互作用はエンゲージメントに正 の影響を与える (Adhikari \& Panda, 2019; Harmeling, Moffett, Arnold, \& Carlson, 2017; Vivek et al., 2012)。ま た，ブランドのコアバリュー（価值）を消費者が理解し ていたり, ニーズにフィットしていたりするほど, エン ゲージメントは高まる (Adhikari \& Panda, 2019; Rather, Tehseen, \& Parrey, 2018)。

特に近年は，モバイル・テクノロジーとアプリの人気 の高まりにより，多くの企業がモバイル・アプリを通じ て顧客との関係を構築するようになってきている (Tarute, Nikou, \& Gatautis, 2017)。旅行アプリとプラットフォー ムの研究ではあるが，モバイル・アプリのインターフェ イス・デザインや使い勝手の良さ, アプリを通じた挴 な価格などは, プラットフォーム・ブランドのエンゲー ジメントの認知的・感情的・行動的な要素を高め, 結果 的にそのブランドに対する認知やロイヤルテイに正の影 響を与える（Tian, Lu, \& Cheng, 2021）。また，アプリの 情報探索のしやすさや，アプリを通じて楽しめる要素が 
あるほど，認知的・感情的・行動的な要素で構成される エンゲージメントに正の影響を与え，アプリの継続利用 にも正の影響を与えている（Qing \& Haiying, 2021）。こ のようにアプリを通じた顧客との接点はエンゲージメン トに正の影響を与えると考えられる。アプリを通じたブ ランドサイトの情報やコラム, ブログやブランドが発信 する Instagram や Facebook などの SNS へのフォローやい いね！など，多様なタッチ・ポイントを通じたブランド との相互作用が，エンゲージメントの認知的・感情的・ 行動的な要素のそれぞれに影響することが検討されてき た（Eigenraam et al., 2018）。さらに，ブランド・アプリ の存在は, ブランドの認知や態度, 関係性に正の影響を 与える存在である（van Noort \& van Reijmersdal, 2019）。 上記の点から，ブランドに対する評価やアプリを通じた ブランドとの関倸は，エンゲージメントに正の影響を与 えると考える。これらの点から以下の仮説（H1, H2a, H2b）を設定する。

H1 : ブランド評価は, エンゲージメントの形成に正の 影響を与える。

H2a：アプリを通じた接点が多いほど，エンゲージメ ントの形成に正の影響を与える

$\mathrm{H} 2 \mathrm{~b}$ ：アプリを通じた接点が多いほど，ブランド評価 に正の影響を与える

「購買」を中心としたこれまでの消費者行動研究におい て，ブランドに対する態度や評価は，満足度に影響する と考えられてきた（e.g. Ono, Ogawa, \& Morikawa, 2021)。 またブランド・エクイティは満足度に強く影響すること がメ夕分析の結果からも示されている（Szymanski \& Henard, 2001）。そこで以下の仮説（H3）を設定する。

H3：ブランド評価は, 満足度に正の影響を与える。

次に，エンゲージメントと満足度やロイヤルティとの 関係について議論する。これまでの消費者行動研究にお いて, 顧客のブランドに対するロイヤルティは, 認知的・ 感情的・意欲的ロイヤルティを経て，形成されること (e.g. Fournier, 1998; Oliver, 1999)，そして「真のロイヤル
ティ」は, 認知的, 感情的な態度が伴った購買行動によっ て形成されることが議論されてきた（Dick \& Basu, 1994; Keller, 1998; Ono et al., 2021)。実際に近年の日本におけ る小売業を含めたサービス領域に扔いても（業種や業態 によってバラツキはあるが), 顧客満足はロイヤルティ （再購買意図）に正の影響を与えることが長年の研究の成 果から明らかになってきている（Ono et al., 2021）。

近年のエンゲージメント研究に押いても, エンゲージ メントが満足度やロイヤルテイに影響を与えるという流 れで研究が進んできている（Adhikari \& Panda, 2019; Dwivedi, 2015; Fernandes \& Moreira, 2019; Hollebeek, 2011; Leckie et al., 2016; Rather et al., 2018)。

これらの点をふまえると, 顧客とブランドとの多様な 関わりや，使用経験を通じて形成されるエンゲージメン トが前提となり, 同じブランドを買い続けようとする意 図としての満足度, その満足度がベースとなって, 感情 的・意欲的なロイヤルティが形成されると考元られる (Oliver, 1999; Ono et al., 2021)。さらに, 実際の購買行動 が伴った状態にある「真のロイヤルティ」とは，良いク チコミの発生や顧客の長期的なりピート購入を伴う売上 増加とそれに伴うオペレーションコストの低減, 収益性 の向上につながるものである（e.g. Dick \& Basu, 1994; Keller, 1998; Oliver, 1999; Ono et al., 2021)。そこで以下の 仮説（H4, H5, H6）を設定する。

$\mathrm{H} 4$ ：エンゲージメントは, 満足度に正の影響を与える $\mathrm{H} 5 ：$ 満足度はロイヤルティに正の影響を与える

H6：ロイヤルティは，購買行動と正の関係がある

なお，実務において，主にデジタル・マーケティング は上記で紹介したような SNSへの「いいね!」の数や フォロワー数，インプレッション数などを「KPI」(Key Performance Indicator）として活動している。これらの活 動が, エンゲージメントの認知的・感情的・行動的な要 素を高め（Eigenraam et al., 2018），エンゲージメントが 「購買行動を促す要因になる」と信じて活動している。そ こで，本研究は実務のニーズを反映するために探索的な 確認として「エンゲージメントは購買行動と正の関係が ある」と設定し，ダイレクトパスを設定した。ここまで 


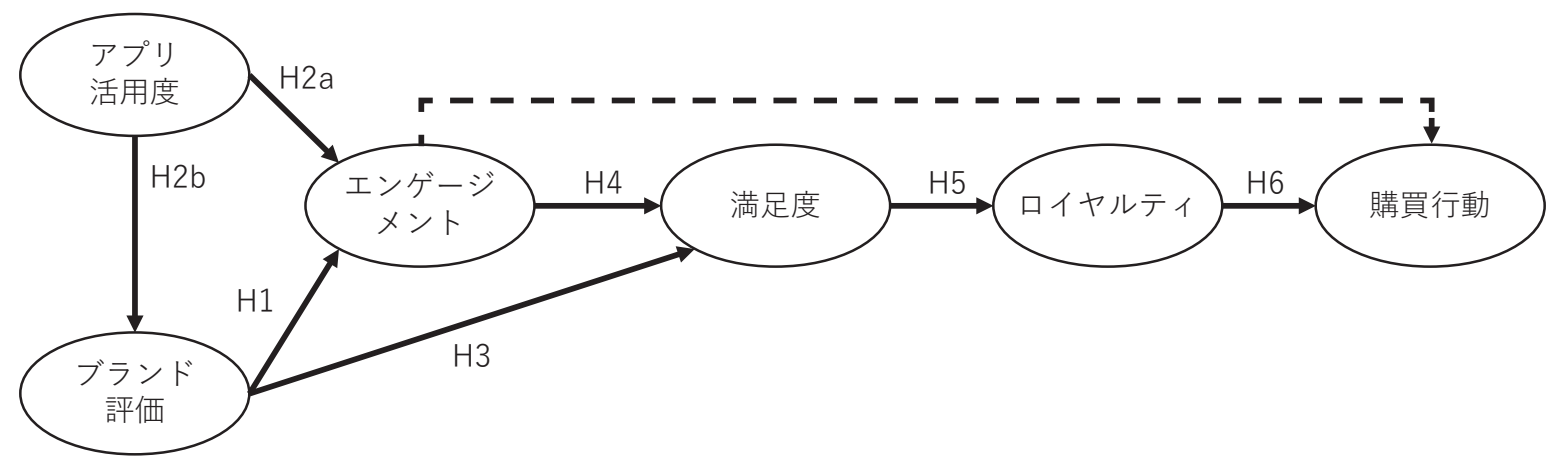

の仮説モデルを図 1 に示す。

\section{III. 実証分析}

\section{1. 調査対象企業：服飾雑貨 SPA ブランド}

これまでのエンゲージメント研究で掲載されている ジャーナルの上位は, Journal of Services Marketing, Journal of Product and Brand Management, Journal of Retailing and Consumer Services, Journal of Marketing Management, Journal of Service Research, Journal of Service Management などであり，サービス・マーケティング，製品ブランド・ マネジメント, マーケティング・マネジメント系である (Rosado-Pinto \& Loureiro, 2020)。これらの経緯から，今 回の研究には, 大手服飾雑貨 SPA ブランドを選んだ。自 社で商品開発も行い, 自社店舗での品揃えと良心的な接 客を通じたサービスを行い, 2021 年現在, 日本と中国の 都心部と郊外の両方に約 500 店舗以上を展開している。 また，アプリは 2021 年 8 月時点で 380 万人以上がダウ ンロードしており，ECサイトによる通販も展開する。 一般的な購買頻度は年に数回あることから, 本研究の対 象としてふさわしいと判断し，分析を進めた。

\section{2. アプリ会員およびハウス・ホールド・パネルへの調査}

顧客データベースから，メインターゲットである 18 歳から 45 歳までの女性, かつ, ゴールド会員（年間 5,000 円以上の購買額), ダイヤモンド会員 (年間 1 万円以上
の購買額）の条件に該当する顧客を抽出し，2020 年 10 月から 12 月の間に, ZOOM を用いたオンライン・デプ ス・インタビューを 12 名の顧客に行った。店舗や EC サ イト，アプリを通じたタッチ・ポイント上での評価をつ ぶさに確認し, この内容を元にブランド評価の項目を設 計した（項目は表 3 に示す，分析にも使用する）。

次に, マクロミル社の調査システム「Questant」を用 いて質問票を作成し，インターネットによる量的調查を 2021 年 1 月 6 日から 11 日, および, 1 月 18 日〜24 日で 実施した。合計 1,501 名のサンプルを回収したが，この ブランドを購入したことがない「未購入者」や「非認知 者」を分析対象から除外し, 867 サンプルを分析対象に 用いた。回答者属性は, 全員女性であり, 年齢構成比は, この企業のターゲット年齢で分けられた区分の $13 \sim 17$ 歳（ピュアヤング）が 16 名, 18〜24 歳（ヤング）が 180 名, 25〜34 歳（ヤングキャリア）が 293 名, 35〜44 歳 (ヤングミセス) が 176 名, 45 歳以上（ミセス）が 202 名である。

\section{3. カスタマー・ブランド・エンゲージメントの概念化}

認知的・感情的・行動的な要素でエンゲージメントの 概念化を進めている Dwivedi (2015), Eigenraam et al. (2018), Fernandes and Moreira (2019), Hollebeek et al. （2014）を元に, 尺度を作成した（表 1 参照）。IBM SPSS （ver. 27）で探索的因子分析（最尤法，バリマックスによ る直交回転）を行い，共通性の低い項目を削除した後， IBM SPSS Amos（ver. 27）で確認的因子分析を行った。 


\begin{tabular}{|c|c|c|c|c|}
\hline 因子 & 質問項目 & 因子負荷量 & CR & AVE \\
\hline & C1：【このブランド】を使っていると, 全てのことを忘れさせてくれる & 0.847 & & \\
\hline 認知的 & C2：【このブランド】と関わると時間を忘れてしまう & 0.830 & & \\
\hline エンゲージ & C3 : 〔このブランド】を使っているとき, このブランドのことを色々と考える & 0.897 & 0.936 & 0.747 \\
\hline \multirow[t]{2}{*}{ メント } & C4：【このブランド】を使っているとき, このブランドについて考えさせられる & 0.874 & & \\
\hline & C5：【このブランド】を使うほど, このブランドをもっと知りたいという興味が刺激される & 0.872 & & \\
\hline \multirow{4}{*}{$\begin{array}{c}\text { 感情的 } \\
\text { エンゲージ } \\
\text { メント }\end{array}$} & E1：【このブランド】は私を幸せにしてくれる & 0.905 & \multirow{4}{*}{0.912} & \multirow{4}{*}{0.759} \\
\hline & $\mathrm{E} 2$ ：【のの゙ランド】を使うと, とてもポジティブな気分になる & 0.872 & & \\
\hline & E3：【このブランド】を使うと気分が良くなる & 0.878 & & \\
\hline & E4：【このブランド】を使うことが誇らしい & 0.830 & & \\
\hline 行動的 & B1：下着や靴下を使うときに, 【このブランド】はよく使用するブランドの 1 つである & 0.825 & & \\
\hline エンゲージ & B2：他のブランドと比べて, 私は【このブランド】商品を使って過ごす時間が多い & 0.911 & 0.904 & 0.758 \\
\hline メント & B3：下着や靴下を使うときは, いつも【このブランド】を使っている & 0.874 & & \\
\hline \multirow{4}{*}{ 満足度 } & S1：私が 【このブランド】を選ぶことは賢い選択だと思う & 0.893 & \multirow{4}{*}{0.932} & \multirow{4}{*}{0.775} \\
\hline & S2：【このブランド】は私の期待に沿っている & 0.895 & & \\
\hline & S3：私は【このブランド】を買うことが正解だと思う & 0.886 & & \\
\hline & S4：私は【このブランド】に満足している & 0.847 & & \\
\hline \multirow{3}{*}{$\begin{array}{c}\text { ロイヤル } \\
\text { ティ }\end{array}$} & $\mathrm{R} 1$ : 私は【このブランド】の熱狂的なファンである & 0.888 & \multirow{3}{*}{0.886} & \multirow{3}{*}{0.722} \\
\hline & $\mathrm{R} 2$ ：私は【このブランド】に入れ込んでいる（コミットしている） & 0.882 & & \\
\hline & R3 : 私は家族や友人に【このブランド】をオススメする & 0.774 & & \\
\hline
\end{tabular}

注 :【このブランド】と表記している部分は, 調査の際はブランド名を入れて実施している。

\begin{tabular}{crrrrr}
\hline 因子 & 認知的 & \multicolumn{1}{l}{ 感情的 } & 行動的 & 満足度 & ロイヤルティ \\
\hline 認知的 & 0.864 & & & & \\
感情的 & 0.723 & 0.871 & & & \\
行動的 & 0.623 & 0.752 & 0.870 & & \\
満足度 & 0.610 & 0.862 & 0.815 & 0.880 & \\
ロイヤルティ & 0.799 & 0.785 & 0.844 & 0.793 & 0.848 \\
\hline
\end{tabular}

注：表の対角線にはAVE の平方根を表記し，その下の段は因子間の相関係数を示している。 表記について, 認知的 : 認知的エンゲージメント, 感情的：感情的エンゲージメント, 行動 的：行動的エンゲージメントをそれぞれ示している。

適合度指標として用いた CFI（>0.90 以上で良い）は 0.946, Hoelter (0.05) は 143 (サンプル数の 867s の方 が, このスコアより大きければ $\chi^{2}$ 検定が棄却された可能 性があるため他の適合度指標と併せて検討）（Toyoda， 2007), Standardized RMR（以下, S RMR), RMSEA は, 0.05 以下で良好， 0.1 以上で良くないと判断されるもの で, S RMR は 0.051, RMSEA は 0.085 となった。RMSEA のスコアがやや低いものの，許容範囲である。パスはす ベて有意であり，適合度指標は概ね高いスコアであった ことから，分析を進めた。
次に, 尺度の信頼性, 弁別性について確認した（表 2 参照）。合成信頼性（CR）はいずれも基準值の 0.6 を超 えていることから, 信頼性は十分なスコアを示した。AVE (average variance extracted）はいずれも, 基準值の 0.5 を 大きく上回っており, 収束妥当性も問題ない。弁別妥当 性は, Fornell and Larcker（1981）に従い, AVE の平方根 と因子間相関との比較により検証を行なった（表 2 参 照)。その結果, 他の因子間相関よりも AVE の平方根の 方が高い值を示したため, 弁別妥当性が担保できている と判断し，次の分析に進めた。 


\section{4. 購買履歴データを含めたエンゲージメントの包括モ} デル

ブランド評価の項目は, 探索的因子分析（最尤法，バ リマックス回転, 寄与率 $57.8 \%$ ）を行い，4つの因子「品 揃え」「コストパフォーマンス」「商品力」「店舗・サービ ス対応」に分類し, 分析に用いた（表 3 参照）。アプリ の利用状況で確認していた項目は,「会員証として利用し ている」「コラムやコーディネートなどの商品以外の情報 を得る」「キャンペーン情報を得る」「購入履歴を確認す る」などの 9 項目による複数回答（ダミー変数）であっ たため，スコアの合計值として利用した。

次に，購買行動に関するデータについて説明する。対 象となる期間は, 2017 年 10 月から 2021 年 1 月調査時点 までの約 3 年分の購買履歴データである。トランザク ションデータは 1,342 万 1,770 件であり， SPSS Modeler を用い，ID（アプリ会員番号）で集計したところ，158 万 711 件の取引データがあった。上記の調査データと マッチングしたところ，136 名の対象者が合致した。そ こで，このデータを用いて包括モデルを作成する。

今回の分析に用いた変数は,「顧客期間」,「直近購買 日」,「購買回数」,「購買金額」である。これらの変数は, 顧客のロイヤルティを測定するための最も重要な変数で ある（cf. Abe, 2011; Harada, 1998）。顧客期間は上記 3 年 間で，直近の購買日から最も過去の購買日を差し引いた
日数である（平均 299.7 日，標準偏差 358.3）。これが長 いほど顧客である期間が長い。直近購買日は, 調査日の 2021 年 1 月 21 日を基点に計算した（平均 94.5 日，標準 偏差 171.9)。購買回数は, 上記の期間内における購買回 数を計算し（平均 11.9 回，標準偏差 10.4）, 購買金額は, この期間における購買の合計額である（平均 3 万 1,850 円，標準偏差 40,960.8)。

上記の変数を含めた仮説モデルを検証するために, IBM SPSS Amos（ver. 27）で構造方程式モデルを作成し, 分 析を行った（図 2 参照）。適合度指標として用いた, CFI （>0.90 以上で良い）は 0.815 , Hoelter (0.05) は 83（サ ンプル数の $136 \mathrm{~s}$ の方が, このスコアより大きければ $\chi^{2}$ 検定が棄却された可能性があるため他の適合度指標と併 せて検討）（Toyoda, 2007），S RMR は 0.081，RMSEA は 0.075 となった。適合度指標はやや低下したものの, モ デルの複雑性を考えた場合，十分な適合度であること， さらに，仮説検証のための統計的確認は判断できること から,このモデルで解釈を進めた。

分析の結果, 仮説：H2a（アプリの活用度からエンゲー ジメントへのパス）, および, 仮説 : H3（ブランド評価 から満足度へのパス）は裹却された。また，エンゲージ メントから購買行動への探索的なパスは有意であったも のの, そのスコアは負の影響となった。それ以外の, 仮 説：H1（ブランド評価からエンゲージメントへのパス）,

\begin{tabular}{clc}
\hline 因子 & \multicolumn{1}{c}{ 質問項目 } & 標準化係数 \\
\hline & AS1 : 商品の種類が豊富 & 0.78 \\
& AS2 : カラーバリエーションが豊富 & 0.72 \\
& AS3 : 商品にトレンド感がある & 0.74 \\
品 & AS4 : 新商品が多い & 0.74 \\
揃 & AS5 : 商品のデザインがよい & 0.74 \\
え & AS6 : 商品の在庫がきちんとある & 0.61 \\
& AS7 : サイズバリエーションが豊富 & 0.72 \\
& AS8 : レッグウェア, 下着, ホームウエア゙全て揃う & 0.80 \\
& AS9 : 陳列が見やすい & 0.63 \\
\hline パ & EF1 : 価格が安い & 0.70 \\
フ & EF2 : コストパフォーマンスが良い & 0.80 \\
オ コ & EF3 : セールが魅力的 & 0.69 \\
I ス & EF4 : お店に入りやすい & 0.57 \\
ン & EF5 : キャンペーンや割引が魅力的 & 0.67 \\
ス & EF6 : 自分の行動範囲に店舗がある & 0.41 \\
\hline
\end{tabular}

\begin{tabular}{|c|c|c|}
\hline 因子 & 質問項目 & 標準化係数 \\
\hline \multirow{6}{*}{$\begin{array}{l}\text { 製 } \\
\text { 品 } \\
\text { 力 }\end{array}$} & PR1：着心地・履き心地がよい & 0.60 \\
\hline & PR2：商品の品質（素材や縫製など）がよい & 0.77 \\
\hline & PR3：商品の機能性（保温や着圧など）がよい & 0.77 \\
\hline & PR4：欲しい商品がある & 0.73 \\
\hline & $\begin{array}{l}\text { PR5：自分の好きなスタイル（カジュアルやフェミニン } \\
\text { など）の商品がある }\end{array}$ & 0.78 \\
\hline & PR6 : シンプル, またはベーシックなデザインがある & 0.59 \\
\hline \multirow{6}{*}{$\begin{array}{l}\text { サ } \\
\text { l. 店 } \\
\text { 㦷 } \\
\text { 詨 } \\
\text { 応 }\end{array}$} & SE1：店員に相談しやすい & 0.63 \\
\hline & SE2 : 店員の接客が丁寧だ & 0.72 \\
\hline & SE3：試着しやすい & 0.63 \\
\hline & $\mathrm{SE} 4 ：$ 店舗の雲囲気がよい & 0.80 \\
\hline & SE5：店舗のデザインがよい & 0.78 \\
\hline & SE6：お買い物袋が可愛い & 0.53 \\
\hline
\end{tabular}

標準化係数は，全て $1 \%$ リクグ有意 $(* * *: p<0.01)$ 


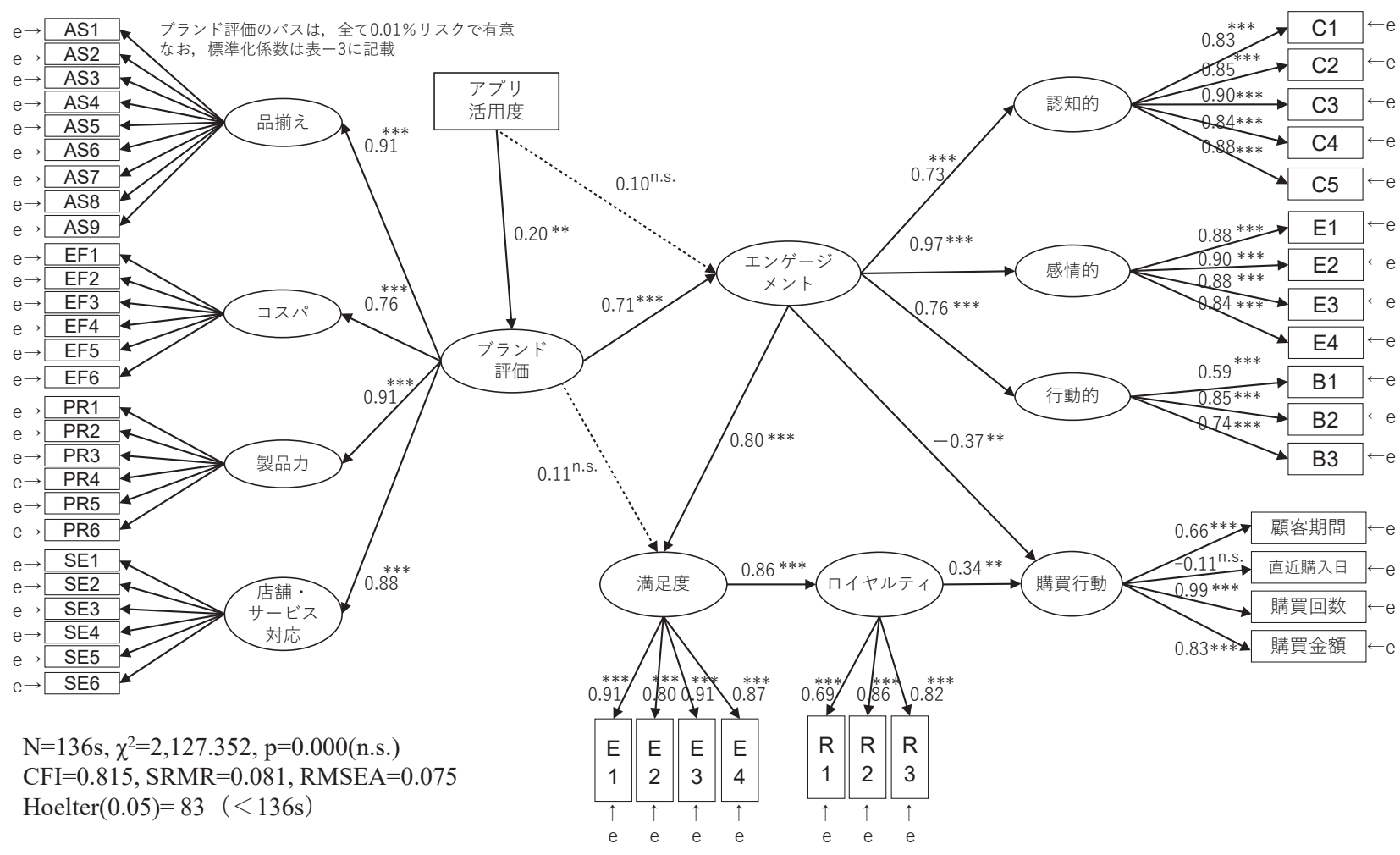

*** $\mathrm{p}<0.01, * * \mathrm{p}<0.05,{ }^{*} \mathrm{p}<0.1$, n.s. 有意差なし

仮説：H2b（アプリ活用度からブランド評価へのパス）, 仮説：H4（エンゲージメントから満足度へのパス），仮 説：H5（満足度からロイヤルティへのパス）, 仮説 : H6 （ロイヤルティから購買行動へのパス）はいずれも正の影 響となり，これらの仮説は検証された。

\section{IV. まとめと今後の課題}

今回の分析で明らかになった点は大きく 2 点ある。第 一に, 最も重要な点は, エンゲージメントが, 満足度と ロイヤルティを経由し, 購買行動の「顧客期間」,「購買 金額」,「購買回数」と正の関係にあったことである（た だし，「直近購買日」は，統計的な有意差はなかった）。 実際の購買履歴データを分析モデルに組み込むことで, エンゲージメントが真のロイヤルティ（つまりは企業の
収益性の向上）を導く存在であることを明らかにした点 が本研究の最大の貢献である。ただし，エンゲージメン トから購買行動への直接のパスは負の影響となったこと から, エンゲージメントだけを高めても意味は無く, 満 足度とロイヤルティを形成しなければ, 購買行動（収益 性の向上）にはつながらないことも明らかになった。

第二に，エンゲージメントを高めるために必要な要素 は, ブランド評価であった。アプリの存在はブランド評 価に正の影響を与えているものの，エンゲージメントに はブランド評価のみが正の影響を与えていた。なお，ブ ランド評価から満足度への直接のパスは棄却されたこと から, 顧客との多様な接点があるデジタルな時代におい ては, エンゲージメントを高めなければ満足度やロイヤ ルティは高まらない点も明らかにした。

本研究の分析対象とした服飾雑貨 SPA ブランドの場合 であれば，特に製品力や品揃えがエンゲージメントに強 
く影響しており, 次いで, 店舗・サービス対応やコスト パフォーマンスが影響していた。アプリを含めた顧客と のタッチ・ポイントを通じて，これらのブランド評価に 影響する（あるいは評価を高める）要素を伝えながら， 施策を実施し続けることが，エンゲージメントを高め， 満足度，ロイヤルティを経て購買行動（収益性の向上） につなぐことが重要となる。

最後に本研究の課題について述べる。まず，今後，よ り多くのサンプルでの実証分析を行うことで結果の頑強 性を高めることが求められる。さらに, 服飾雑貨の他の 企業や，異なる業界でも同様の包括モデルを通じた確認 が可能となれば，エンゲージメントの理論的・実務的発 展に大きく寄与できるものと考える。今後も継続して研 究を進めていく予定である。

\section{謝辞}

本研究は令和 2 年度 科学研究費 基盤 (C) 課題番号 20K01977「スマート・フォンのデザイン性と利用状況が ブランド・ロイヤルティに与える影響」の助成を受けて 進めたものである。共同研究先の服飾雑貨 SPA ブランド 企業では，代表や役員，CX（カスタマー・エクスペリエ ンス）メンバーをはじめ, 多くの方に日々, 協力して頂 いている。また, マーケティングレビューのシニアエディ ター, マーケティング・カンファレンス 2021 オーラル ペーパーの査読者からは改稿のための貴重なコメントを 頂いた。ここに感謝の意を表する。

\section{References}

Abe, M. (2011). RFM shihyou to kokyaku shougai kachi: Kaisou Bayes model wo tsukatta hikeiyakugata kokyaku kankei kanri ni okeru shouhisha koudou no bunseki. Journal of the Japan Statistical Society, 41(1), 51-81.（阿部誠（2011）。「RFM 指標 と顧客生涯価值：階層ベイズモデルを使った非契約型顧客 関係管理における消費者行動の分析」『日本統計学会誌』 41(1), 51-81) (In Japanese)

Adhikari, K., \& Panda, R. K. (2019). The role of consumer-brand engagement towards driving brand loyalty: Mediating effect of relationship quality. Journal of Modelling in Management, 14(4), 987-1005.

Dick, A., \& Basu, K. (1994). Customer loyalty: Toward and integrated conceptual framework. Journal of the Academy of Marketing Science, 22(2), 99-113.

Dwivedi, A. (2015). A higher-order model of consumer brand engagement and its impact on loyalty intentions. Journal of Retailing and Consumer Services, 24(C), 100-109.

Eigenraam, A. W., Eelen, J., van Lin, A., \& Verlegh, P. W. J. (2018). A consumer based taxonomy of digital engagement practices. Journal of Interactive Marketing, 44 (November), 102-121.

Fernandes, T., \& Moreira, M. (2019). Consumer brand engagement, satisfaction and brand loyalty: A comparative study between functional and emotional brand relationships. Journal of Product and Brand Management, 28(2), 274-286.

Fornell, C., \& Larcker, D. F. (1981). Evaluating structural equation models with unobservable variables and measurement error. Journal of Marketing Research, 18(1), 39-50.

Fournier, S. (1998). Consumers \& their brands: Developing relationship theory in consumer research. Journal of Consumer Research, 24 (March), 343-373.

Harada, T. (1998). RFM no database marketing katsuyou. Kagawa University Economic Review, 71(3), 95-149.（原田保（1998）. 「RFM のデータベースマーケテイング活用」『香川大学経済 論叢』71(3), 95-149）(In Japanese)

Harmeling, C. M., Moffett, J. W., Arnold, M. J., \& Carlson, B. D. (2017). Toward a theory of customer engagement marketing. Journal of the Academy of Marketing Science, 45(3), 312-335.

Hollebeek, L. D. (2011). Demystifying customer brand engagement: Exploring the loyalty nexus. Journal of Marketing Management, 27(7-8), 785-807.

Hollebeek, L. D., Glynn, M. S., \& Brodie, R. J. (2014). Consumer brand engagement in social media: Conceptualization, scale development and validation. Journal of Interactive Marketing, 28(2), 149-165.

Keller, K. L. (2008). Strategic brand management: Building, measuring, and managing brand equity. New Jersey: Pearson Prentice Hall.

Leckie, C., Nyadzayo, M. W., \& Johnson, L. W. (2016). Antecedents of consumer brand engagement and brand loyalty. Journal of Marketing Management, 32(5-6), 558-578.

Oliver, R. L. (1999). Whence consumer loyalty? Journal of Marketing, 63 (Special Issue), 33-44.

Ono, J., Ogawa, K., \& Morikawa, H. (2021). Service excellence: CSI shindan ni yoru kokyaku keiken [CX] no kashika. Tokyo: Seisansei shuppan. (小野譲司・小川孔輔・森川秀樹 (2021). 『サービスエクセレンス：CSI 診断による顧客経験 $[\mathrm{CX}]$ の可視化』生産性出版）(In Japanese)

Pansari, A., \& Kumar, V. (2017). Customer engagement: The construct, antecedents, and consequences. Journal of the Academy of Marketing Science, 45(3), 294-311.

Qing, T., \& Haiying, D. (2021). How to achieve consumer continuance intention toward branded apps-From the consumer-brand engagement perspective. Journal of Retailing and Consumer Services, 60(February), 1-8.

Rather, R. A., Tehseen, S., \& Parrey, S. H. (2018). Promoting customer brand engagement and brand loyalty through customer brand identification and value congruity. Spanish Journal of Marketing-ESIC, 22(3), 321-341.

Rosado-Pinto, F., \& Loureiro, S. M. C. (2020). The growing 
complexity of customer engagement: A systematic review. EuroMed Journal of Business, 15(2), 167-203.

Szymanski, D. M., \& Henard, D. H. (2001). Customer satisfaction: A meta-analysis of the empirical evidence. Journal of the Academy of Marketing Science, 29(1), 16-35.

Tarute, A., Nikou, S., \& Gatautis, R. (2017). Mobile application driven consumer engagement. Telematics and Informatics, 34(4), 145-156.

Tian, Z., Lu, M., \& Cheng, Q. (2021). The relationships among mobile travel application attributes, customer engagement, and brand equity. Social Behavior and Personality, 49(7), 1-10.

Toyoda, H. (2007). Kyoubunsan kouzou houteisiki [Amos hen] kouzou houteisiki modeling. Tokyo: Tokyo tosho.（豊田秀樹 (2007)。『共分散構造分析 [Amos 編 $]$ : 構造方程式モデリ ング』東京図書) (In Japanese)

van Noort, G., \& van Reijmersdal, E. A. (2019). Branded apps: Explaining effects of brands' mobile phone applications on brand responses. Journal of Interactive Marketing, 45, 16-26.

Vivek, S. D., Beatty, S. E., \& Morgan, R. M. (2012). Customer engagement: Exploring customer relationships beyond purchase. Journal of Marketing Theory and Practice, 20(2), $127-145$. 